\title{
ÜNIVERSITEPARK Bülten
}

ISSN 2147- 351X (Print)

\section{ÜNIVERSITEPARK Bülten・Volume 4 •Issue 1-2 • 2015}

The Role of Reading Skills on Reading Comprehension Ability of Turkish EFL Students

\section{Ebru Kaya}

To cite this article: Kaya, E. (2015). The Role of Reading Skills on Reading Comprehension Ability of Turkish EFL Students. Üniversitepark Bülten, 4(1-2), 37-51. 


\title{
The Role of Reading Skills on Reading Comprehension Ability of Turkish EFL Students
}

\author{
EBRU KAYA
}

\begin{abstract}
Reading is a part of our daily lives. It is performed both for pleasure and information. Reading skills are important for the individuals since they foster comprehension in reading. If the students do not have knowledge of reading skills, they cannot be expected to be successful readers. Thus, they cannot achieve the level of comprehension required to pass exams in their own departments. For this reason, reading skills should be taught in universities for the students to be able to cope with comprehension problems. This case study aims to find out whether or not reading skills has a role on the reading comprehension ability of Turkish EFL students. This study is both a qualitative and a quantitative study which lasted for a duration of 14 weeks. Two groups were selected (experimental and control) among prep classes at Kahramanmaraş Sütçü Imam University. Both groups were administered a pre-test and questionnaire at the beginning of the study to find out if they were aware of reading skills. In addition, 10 students were chosen randomly for interview. During the study, reading skills were infused into the curriculum through designing lesson plans in accordance with the language content and topics for level $\mathrm{C}$ students, as determined by the Common European Language Framework. The lessons required the students to use reading skills before, during, and post reading. At the end of the study, the same questionnaire was re-administered. The students were given the post-test and then interviewed. The quantitative data were analyzed through descriptive statistics. The obtained data revealed that the students enhanced their comprehension ability provided that they were taught to use reading skills.
\end{abstract}

Keywords: reading skills, reading comprehension, Turkish EFL students.

ISSN 2147-351X @ 2015

Copyright (C) 2015 by ÜNIVERSITEPARK Limited 


\section{Introduction}

EFL reading is a process which has been investigated for decades. Reading is a familiar part of our everyday lives for most of us. Scholars and researchers in the field have been trying to understand the details of the process.

By the 1970s, reading research in native language had been flourishing for a couple of decades as researchers were trying to understand why some children could not read. However, research on reading in a second language is almost nonexistent. After Kenneth Goodman's (1967) article, "Reading: A Psycholinguistic Guessing Game", experts of second languages started to deal with the issues and questions of second language reading pedagogy (as cited in Brown, 2001).

The word reading is often used to describe both what beginners do when they are learning to read and what good readers do when they are involved in fluent reading. However, the two kinds of readers do different things and therefore have very different needs as they struggle to become better readers. Reading at these two extremes of skill, and at the various levels of proficiency between them, is a series of activities which presuppose different levels of knowledge, different needs and purposes. It should be apparent; then, that what may be true about reading at some particular level of proficiency may not be true at all of reading at much higher or much lower levels. Reading is primarily a cognitive process, and the key to fluent reading is not a kind of visual gymnastics, but knowledge (Eskey, 1983; Kalayci \& Humiston, 2015; Rathert, 2012).

Reading is a self-discovery process. During this process, readers interact with written materials by investing both cognitive and metacognitive efforts to decompose new knowledge so as to make or infer meaning. From this point of view, reading comprehension can be seen as the final product (Hellyer, Robinson, \& Sherwood, 2001; Kalayci, 2012).

Traditionally, reading is a passive activity, but in fact, it should be active. As Block (1992) indicates, reading is such a hidden process that it is often unnoticed in the language classroom. Teachers often believe that reading classes should be teacher-centered. According to Bedir (1998), if teachers adopt rote learning, learners are usually expected to tackle comprehension difficulties by themselves.

Moreover, teachers must focus not only on language development, but also on reading strategy practice. Rivas (1999) notes that language problems seem to be the most frequent source of reading difficulties confronted by EFL learners at intermediate level. Thus, we must focus on reading skills as well as language problems.

It is a fact that reading in a foreign language is strongly linked with thinking in that language. If you want to read well in English, you must think in English as you read. If you think in another language and translate into English, you will usually have difficulty with comprehension. According to Bedir (1998), this is time-consuming and the result is usually incomplete comprehension. Understanding the words and the grammar is not enough while reading. The learner needs to make logical connections between the ideas and information in reading. This means using the information the learner already knows to reach a conclusion.

Turkish EFL students are not exposed to training in reading skills. The students do not know how to activate their schemata. Thus, they encounter difficulties in comprehension. 
This results in poor marks in reading sections of their examinations. As observed by the researcher, the students complain about their marks and they do not know how to tackle texts in English. However, if reading skills, such as finding the main idea and contextual clues are emphasized in the training period, the students might be more successful in reading comprehension.

There exists numerous studies on reading skills and comprehension. Alderson (2000) notes that the readers' knowledge affects what they understand. There are other factors which affect reading comprehension. According to Mikulecky and Jeffries (2004), reading comprehension is a problem for many students. When they read in English, they tend to attribute the comprehension difficulties to the English language. They may also feel that the problem is their own lack of ability. In fact, the problem is about their approach to a text. If the students understand how the information is presented in English texts and are aware of the cognitive processes, they will be better at comprehension.

This study aims at finding out the strategies / skills that students employ to interpret what they read by means of clues, and reflect on what the text does by making such remarks. It also aims at discovering how the students look for clues in a text; understand the writer's purpose, and how their reading skills affect their comprehension ability. The scope of this study is based on schema theory. According to this theory, reading is an active process which cannot be achieved without background knowledge.

The following are the research questions generated for the study:

- Are the students aware of reading skills?

- Can the students be trained in terms of reading skills?

- Are the students who are trained on reading skills better at reading comprehension than those who are not?

\section{Methodology}

This study was designed as a case study, and the aim is to enhance reading skills of the 50 students in the preparatory year. Qualitative and quantitative research designs were both used in the study. It presents data about the development of reading skills of the participants and their perceptions and attitudes towards reading. The data was gathered through pre-test and post-test, and a Reading Skills Questionnaire, which were supported by interviews.

The participants of the study were 50 preparatory year students at Kahramanmaraş Sütçü Imam University (KSU). They attended undergraduate programs of economy, business administration and public administration. The students are all in level $C$ in English proficiency. They attended two classes: C4 and C7. C4 was set as the control group and C7 as the experimental group. There were 24 students in $\mathrm{C} 4$ and 26 students in $\mathrm{C} 7$ at the time of the study.

The participants had 28 hours of English classes a week throughout the academic year. They were informed about the study at the beginning of the semester. The study lasted 12 weeks. The experiment group received the treatment. The control group did reading classes as determined by the department. The Department of Foreign Languages at KSU has accepted Common European Language Framework as the curriculum of the preparatory 
classes. The experiment grouped received training for two hours a week. The researcher was the instructor of both groups.

The lesson plans were prepared by the researcher and checked by two other colleagues. There were two important points in preparing the lesson plans. The first was infusing the reading skills into the curriculum and the second was finding reading texts and which include the reading skills. In other words, students were expected to accomplish meaningful reading. This can be achieved if new knowledge matches the knowledge stored before. In addition, the aim and content of the class was determined beforehand. The reading skills the researcher aimed to infuse were: recognizing definitions and examples, recognizing enumerations, recognizing headings and subheadings, recognizing signal words, recognizing main ideas in paragraphs and short selections, recognizing the contextual clues for vocabulary, recognizing the organization of a text, recognizing the aim of the author, recognizing the genre of the text, recognizing arguments, evaluating the text, and recognizing the role of background knowledge. Besides these skills, the researcher included three microskills: scanning to locate specifically required information, understanding information not explicitly stated and transcoding information to diagrammatic display.

The classes included three stages: pre-reading, during-reading and post-reading. The reading skills were involved especially in pre-reading and during-reading stages.

The Reading Skills Questionnaire was designed by the researcher considering the skills used while reading by Langan (1992) and Pirozzi (1995). It was conducted the beginning of the study (before the training started) in order to find out if the participants are aware of reading skills, and if so what reading skills they have. This questionnaire was also conducted at the end of the study to check if any difference occurred in the participants' reading skills during the study. The questionnaire consisted of 18 statements.

The statements in the questionnaire were closed and scaled. That is to say, there were five items: "Always", "Usually", "Sometimes", "Rarely", and "Never". Each item was pointed from 1 (Never) to 5 (Always).

Figure 1. Reading skills and questionnaire items

\begin{tabular}{|r|l|c|}
\hline & Reading Skills & Item Number \\
\hline 1 & Recognizing definitions and examples & 8,10 \\
\hline 2 & Recognizing enumerations & 5 \\
\hline 3 & Recognizing headings and subheadings & 1 \\
\hline 4 & Recognizing signal words & 7 \\
\hline 5 & Recognizing main ideas in paragraphs and short selections & 6 \\
\hline 7 & Recognizing the contextual clues for vocabulary & 9 \\
\hline 8 & Recognizing the organization of the text & 12 \\
\hline 9 & Recognizing the genre of a text & 17 \\
\hline 10 & Recognizing arguments & 15 \\
\hline 11 & Evaluating the text & 13,16 \\
\hline
\end{tabular}




\begin{tabular}{|r|l|c|}
\hline 12 & Recognizing the role of background knowledge & 3,14 \\
\hline & Micro Skills & Item Number \\
\hline 1 & Scanning to locate specifically required information & 4 \\
\hline 2 & Understanding information not explicitly stated & 18 \\
\hline 3 & Transcoding information to diagrammatic display & 2 \\
\hline
\end{tabular}

The other instrument employed to collect data for this study was the interview. The questions of the interview were prepared by the researcher. It was conducted both at the beginning and at the end of the study to find out whether or not the participants used the reading skills efficiently.

The last instrument used in this study was the pre-test and the post test. These were given to the participants at the beginning and at the end of the study. The questions included comprehension questions and multiple-choice questions, as suggested by Alderson (2000).

The data collected for this study were analyzed through a statistical program, SPSS (Statistical Package for Social Sciences) for Windows, version 15.0. The participants' responses to the Reading Skills Questionnaire were analyzed using the Wilcoxon Signed Rank Test. The pre-test and post-test were conducted in order to find out whether any meaningful difference occurred before and after the training. The data gathered from the related groups, experimental pre- and post for example, were analyzed through Wilcoxon MatchedPairs Signed Rank Test. The qualitative data (data from the interviews) were analyzed qualitatively.

\section{Findings}

This section offers research findings gathered from the pre-test and the post-test, questionnaires, interviews and tests respectively. The quantitative and qualitative data analysis techniques were administered in the analysis of the data collected by means of pretest and post-test, questionnaires, quizzes. The pre-test administered the beginning of the study consisted of 25 questions prepared to assess the predetermined reading skills. The skills were selected among those indicated by Langan (1992), Pirozzi (1995) and Alderson (2000). The participants were expected to display their knowledge of the reading skills. The post-test administered at the end of the study also consisted of 25 questions. The aim was to find out whether or not a change occurred in the comprehension ability of the participants. The data collected from the related groups, for example experimental pre- and post-, were analyzed through Wilcoxon Signed Rank Test. The data collected from the independent groups were analyzed through Mann-Whitney $U$ - Wilcoxon Rank Sum W Test. Table 1 illustrates the findings. 
Findings from Pre- and Post Tests

Table 1. Pre- and Post-Tests of the Control Group

\begin{tabular}{|l|c|c|c|c|c|c|}
\hline TESTS & $\mathrm{N}$ & Minimum & Maximum & Mean & Mean Rank & $\begin{array}{c}\text { Std. } \\
\text { Deviation }\end{array}$ \\
\hline PRE & 24 & 20.00 & 72.00 & 50.5000 & 8.00 & 13.64456 \\
\hline POST & 24 & 32.00 & 76.00 & 54.5000 & 11.94 & 12.74840 \\
\hline Z Value: -2.744 \\
\multicolumn{5}{l}{ P Value (2-tailed): .006 } \\
\hline
\end{tabular}

Table 2. Pre-Test and Post-Test of the Experimental Group

\begin{tabular}{|l|l|c|c|c|}
\hline \multirow{4}{*}{ Pegative Ranks } & N & Mean Rank & Sum of Ranks \\
\cline { 2 - 5 } & & 0 & .00 & .00 \\
\cline { 2 - 5 } & Oositive Ranks & 26 & 13.50 & 351.00 \\
\cline { 2 - 5 } & Ties & 0 & & \\
\cline { 2 - 5 } & Total & 26 & & \\
\hline Z Value: -4.466 & & & \\
\hline \multicolumn{3}{l|}{ P Value (2-tailed): .000 }
\end{tabular}

The results illustrated in Table 1 and Table 2 indicate that there is a statistically significant change at ,000 level between the pre- and post-tests of the experimental group. However, the results of the control group did differ from these results, since the $p$ value is .006 in the control group.

As can be seen from Table 2, there is a statistically significant difference between the post-test results of the control and experimental groups at .000 level. In other words, there is a remarkable difference between the two groups.

\section{Findings from Reading Skills Questionnaire}

The Reading Skills Questionnaire administered at the beginning of the study consisted of 20 items. The students were directed to display their preferences on a five-point scale questionnaire as "Always", "Usually", "Sometimes", "Rarely", and "Never". The same questionnaire was also administered at the end of the study in order to figure out whether or not there existed any changes in the preferences of the participants.

Table 3 displays the data obtained from the pre- and post-questionnaire of the experimental group.

Table 3. Pre- and Post-Questionnaire of the Control Group

\begin{tabular}{|c|l|r|r|r|r|c|}
\hline \multicolumn{2}{|c|}{ PRE-POST } & N & $\begin{array}{c}\text { Mean } \\
\text { Rank }\end{array}$ & Sum of Ranks & Z & $\begin{array}{c}\text { P } \\
\text { (Two-Tailed) }\end{array}$ \\
\hline 1. & Negative Ranks & 6 & 7.50 & 45 & - & .593 \\
& Positive Ranks & 8 & 7.50 & 60 & .535 & \\
& Ties & 10 & & & & \\
& Total & 24 & & & & \\
\hline
\end{tabular}




\begin{tabular}{|c|c|c|c|c|c|c|}
\hline \multicolumn{2}{|r|}{ PRE-POST } & $\mathrm{N}$ & $\begin{array}{l}\text { Mean } \\
\text { Rank }\end{array}$ & Sum of Ranks & Z & $\begin{array}{c}\mathrm{P} \\
\text { (Two-Tailed) }\end{array}$ \\
\hline 3. & $\begin{array}{l}\text { Negative Ranks } \\
\text { Positive Ranks } \\
\text { Ties } \\
\text { Total }\end{array}$ & $\begin{array}{r}6 \\
9 \\
9 \\
24\end{array}$ & $\begin{array}{l}9.42 \\
7.06\end{array}$ & $\begin{array}{l}56.50 \\
63.50\end{array}$ & $\begin{array}{r}- \\
.206\end{array}$ & .837 \\
\hline 4. & $\begin{array}{l}\text { Negative Ranks } \\
\text { Positive Ranks } \\
\text { Ties Total }\end{array}$ & $\begin{array}{r}9 \\
10 \\
5 \\
24\end{array}$ & $\begin{array}{r}9.11 \\
10.80\end{array}$ & $\begin{array}{r}82.00 \\
108.00\end{array}$ & $\begin{array}{r}- \\
.537\end{array}$ & .592 \\
\hline 5. & $\begin{array}{l}\text { Negative Ranks } \\
\text { Positive Ranks } \\
\text { Ties } \\
\text { Total }\end{array}$ & $\begin{array}{r}8 \\
12 \\
4 \\
24\end{array}$ & $\begin{array}{r}12.38 \\
9.25\end{array}$ & $\begin{array}{r}99.00 \\
111.00\end{array}$ & -.228 & .820 \\
\hline 6. & $\begin{array}{l}\text { Negative Ranks } \\
\text { Positive Ranks } \\
\text { Ties } \\
\text { Total }\end{array}$ & $\begin{array}{r}8 \\
9 \\
7 \\
24\end{array}$ & $\begin{array}{l}8.81 \\
9.17\end{array}$ & $\begin{array}{l}70.50 \\
82.50\end{array}$ & -.287 & .774 \\
\hline 7. & $\begin{array}{l}\text { Negative Ranks } \\
\text { Positive Ranks } \\
\text { Ties } \\
\text { Total }\end{array}$ & $\begin{array}{r}8 \\
8 \\
8 \\
24\end{array}$ & $\begin{array}{l}7.25 \\
9.75\end{array}$ & $\begin{array}{l}58.00 \\
78.00\end{array}$ & $\begin{array}{r}- \\
.538\end{array}$ & .590 \\
\hline 8. & $\begin{array}{l}\text { Negative Ranks } \\
\text { Positive Ranks } \\
\text { Ties } \\
\text { Total }\end{array}$ & $\begin{array}{r}6 \\
9 \\
9 \\
24\end{array}$ & $\begin{array}{l}7.75 \\
8.17\end{array}$ & $\begin{array}{l}46.50 \\
73.50\end{array}$ & $\begin{array}{r}- \\
.789\end{array}$ & .430 \\
\hline 9. & $\begin{array}{l}\text { Negative Ranks } \\
\text { Positive Ranks } \\
\text { Ties } \\
\text { Total }\end{array}$ & $\begin{array}{r}8 \\
6 \\
10 \\
24\end{array}$ & $\begin{array}{l}7.75 \\
7.17\end{array}$ & $\begin{array}{l}62.00 \\
43.00\end{array}$ & $\begin{array}{r}- \\
.607\end{array}$ & .544 \\
\hline 10. & $\begin{array}{l}\text { Negative Ranks } \\
\text { Positive Ranks } \\
\text { Ties } \\
\text { Total }\end{array}$ & $\begin{array}{r}9 \\
8 \\
7 \\
24\end{array}$ & $\begin{array}{r}8.00 \\
10.13\end{array}$ & $\begin{array}{l}72.00 \\
81.00\end{array}$ & -.220 & .826 \\
\hline 11. & $\begin{array}{l}\text { Negative Ranks } \\
\text { Positive Ranks } \\
\text { Ties } \\
\text { Total }\end{array}$ & $\begin{array}{r}8 \\
9 \\
7 \\
24\end{array}$ & $\begin{array}{l}8.69 \\
9.28\end{array}$ & $\begin{array}{l}69.50 \\
83.50\end{array}$ & -.337 & .736 \\
\hline 12. & $\begin{array}{l}\text { Negative Ranks } \\
\text { Positive Ranks } \\
\text { Ties } \\
\text { Total }\end{array}$ & $\begin{array}{r}7 \\
9 \\
8 \\
24\end{array}$ & $\begin{array}{l}8.57 \\
8.44\end{array}$ & $\begin{array}{l}60.00 \\
76.00\end{array}$ & -.423 & .672 \\
\hline
\end{tabular}




\begin{tabular}{|c|c|c|c|c|c|c|}
\hline \multicolumn{2}{|r|}{ PRE-POST } & $\mathrm{N}$ & $\begin{array}{l}\text { Mean } \\
\text { Rank }\end{array}$ & Sum of Ranks & Z & $\begin{array}{c}\mathrm{P} \\
\text { (Two-Tailed) }\end{array}$ \\
\hline 13. & $\begin{array}{l}\text { Negative Ranks } \\
\text { Positive Ranks } \\
\text { Ties } \\
\text { Total }\end{array}$ & $\begin{array}{r}8 \\
7 \\
9 \\
24\end{array}$ & $\begin{array}{r}6.25 \\
10.00\end{array}$ & $\begin{array}{l}50.00 \\
70.00\end{array}$ & -.582 & .560 \\
\hline 14. & $\begin{array}{l}\text { Negative Ranks } \\
\text { Positive Ranks } \\
\text { Ties } \\
\text { Total }\end{array}$ & $\begin{array}{r}7 \\
7 \\
10 \\
24\end{array}$ & $\begin{array}{l}6.79 \\
8.21\end{array}$ & $\begin{array}{l}47.50 \\
57.50\end{array}$ & -.322 & .747 \\
\hline 15. & $\begin{array}{l}\text { Negative Ranks } \\
\text { Positive Ranks } \\
\text { Ties } \\
\text { Total }\end{array}$ & $\begin{array}{r}8 \\
12 \\
4 \\
24\end{array}$ & $\begin{array}{l}10.75 \\
10.33\end{array}$ & $\begin{array}{r}86.00 \\
124.00\end{array}$ & -.733 & .463 \\
\hline 16. & $\begin{array}{l}\text { Negative Ranks } \\
\text { Positive Ranks } \\
\text { Ties } \\
\text { Total }\end{array}$ & $\begin{array}{r}10 \\
9 \\
5 \\
24\end{array}$ & $\begin{array}{r}8.30 \\
11.89\end{array}$ & $\begin{array}{r}83.00 \\
107.00\end{array}$ & -.498 & .618 \\
\hline 17. & $\begin{array}{l}\text { Negative Ranks } \\
\text { Positive Ranks } \\
\text { Ties } \\
\text { Total }\end{array}$ & $\begin{array}{r}7 \\
10 \\
7 \\
24\end{array}$ & $\begin{array}{l}9.71 \\
8.50\end{array}$ & $\begin{array}{l}68.00 \\
85.00\end{array}$ & -.409 & .682 \\
\hline 18. & $\begin{array}{l}\text { Negative Ranks } \\
\text { Positive Ranks } \\
\text { Ties } \\
\text { Total }\end{array}$ & $\begin{array}{r}7 \\
12 \\
5 \\
24\end{array}$ & $\begin{array}{r}10.86 \\
9.50\end{array}$ & $\begin{array}{r}76.00 \\
114.00\end{array}$ & -.796 & .426 \\
\hline 19. & $\begin{array}{l}\text { Negative Ranks } \\
\text { Positive Ranks } \\
\text { Ties } \\
\text { Total }\end{array}$ & $\begin{array}{r}8 \\
11 \\
5 \\
24\end{array}$ & $\begin{array}{r}8.50 \\
11.09\end{array}$ & $\begin{array}{r}68.00 \\
122.00\end{array}$ & -1.121 & .262 \\
\hline 20. & $\begin{array}{l}\text { Negative Ranks } \\
\text { Positive Ranks } \\
\text { Ties } \\
\text { Total }\end{array}$ & $\begin{array}{r}8 \\
11 \\
5 \\
24\end{array}$ & $\begin{array}{r}8.50 \\
11.09\end{array}$ & $\begin{array}{r}68.00 \\
122.00\end{array}$ & -.952 & .341 \\
\hline
\end{tabular}

The overall analysis of the items in the questionnaire administered to the control group indicates that reading comprehension ability of the students does not display a significant progress. There is no statistically significant increase between pre- and post- administration of the questionnaire. 
Table 4. Pre- and Post-Questionnaire of the Experimental Group

\begin{tabular}{|c|c|c|c|c|c|c|}
\hline \multicolumn{2}{|r|}{ PRE-POST } & $\mathrm{N}$ & $\begin{array}{l}\text { Mean } \\
\text { Rank }\end{array}$ & Sum of Ranks & Z & $\begin{array}{c}\mathrm{P} \\
\text { (Two-Tailed) }\end{array}$ \\
\hline 1. & $\begin{array}{l}\text { Negative Ranks } \\
\text { Positive Ranks } \\
\text { Ties } \\
\text { Total }\end{array}$ & $\begin{array}{r}4 \\
4 \\
18 \\
26\end{array}$ & $\begin{array}{l}4.50 \\
4.50\end{array}$ & $\begin{array}{l}18.00 \\
18.00\end{array}$ & .000 & 1.000 \\
\hline 3. & $\begin{array}{l}\text { Negative Ranks } \\
\text { Positive Ranks } \\
\text { Ties } \\
\text { Total }\end{array}$ & $\begin{array}{r}2 \\
14 \\
10 \\
26\end{array}$ & $\begin{array}{l}6.00 \\
8.86\end{array}$ & $\begin{array}{r}12.00 \\
124.00\end{array}$ & -3.014 & .003 \\
\hline 4. & $\begin{array}{l}\text { Negative Ranks } \\
\text { Positive Ranks } \\
\text { Ties } \\
\text { Total }\end{array}$ & $\begin{array}{r}3 \\
14 \\
9 \\
26\end{array}$ & $\begin{array}{l}7.50 \\
9.32\end{array}$ & $\begin{array}{r}22.50 \\
130.50\end{array}$ & -2.737 & .006 \\
\hline 5. & $\begin{array}{l}\text { Negative Ranks } \\
\text { Positive Ranks } \\
\text { Ties } \\
\text { Total }\end{array}$ & $\begin{array}{r}3 \\
18 \\
5 \\
26\end{array}$ & $\begin{array}{r}3.50 \\
12.25\end{array}$ & $\begin{array}{r}10.50 \\
220.50\end{array}$ & -3.699 & .000 \\
\hline 6. & $\begin{array}{l}\text { Negative Ranks } \\
\text { Positive Ranks } \\
\text { Ties } \\
\text { Total }\end{array}$ & $\begin{array}{r}5 \\
14 \\
7 \\
26\end{array}$ & $\begin{array}{r}5.50 \\
11.61\end{array}$ & $\begin{array}{r}27.50 \\
162.50\end{array}$ & -2.772 & .006 \\
\hline 7. & $\begin{array}{l}\text { Negative Ranks } \\
\text { Positive Ranks } \\
\text { Ties } \\
\text { Total }\end{array}$ & $\begin{array}{r}2 \\
17 \\
7 \\
26\end{array}$ & $\begin{array}{r}4.50 \\
10.65\end{array}$ & $\begin{array}{r}9.00 \\
181.00\end{array}$ & -3.551 & .000 \\
\hline 8. & $\begin{array}{l}\text { Negative Ranks } \\
\text { Positive Ranks } \\
\text { Ties } \\
\text { Total }\end{array}$ & $\begin{array}{r}0 \\
23 \\
3 \\
26\end{array}$ & $\begin{array}{r}.00 \\
12.00\end{array}$ & $\begin{array}{r}.00 \\
276.00\end{array}$ & -4.256 & .000 \\
\hline 9. & $\begin{array}{l}\text { Negative Ranks } \\
\text { Positive Ranks } \\
\text { Ties } \\
\text { Total }\end{array}$ & $\begin{array}{r}3 \\
13 \\
10 \\
26\end{array}$ & $\begin{array}{l}5.00 \\
9.31\end{array}$ & $\begin{array}{r}15.00 \\
121.00\end{array}$ & -2.814 & .005 \\
\hline 10. & $\begin{array}{l}\text { Negative Ranks } \\
\text { Positive Ranks } \\
\text { Ties } \\
\text { Total }\end{array}$ & $\begin{array}{r}1 \\
12 \\
13 \\
26\end{array}$ & $\begin{array}{l}5.50 \\
7.13\end{array}$ & $\begin{array}{r}5.50 \\
85.50\end{array}$ & -2.949 & .003 \\
\hline
\end{tabular}




\begin{tabular}{|c|c|c|c|c|c|c|}
\hline \multicolumn{2}{|r|}{ PRE-POST } & $\mathrm{N}$ & $\begin{array}{l}\text { Mean } \\
\text { Rank }\end{array}$ & Sum of Ranks & Z & $\begin{array}{c}\mathrm{P} \\
\text { (Two-Tailed) }\end{array}$ \\
\hline 11. & $\begin{array}{l}\text { Negative Ranks } \\
\text { Positive Ranks } \\
\text { Ties } \\
\text { Total }\end{array}$ & $\begin{array}{r}3 \\
23 \\
0 \\
26\end{array}$ & $\begin{array}{r}5.00 \\
14.61\end{array}$ & $\begin{array}{r}15.00 \\
336.00\end{array}$ & -4.112 & .000 \\
\hline 12. & $\begin{array}{l}\text { Negative Ranks } \\
\text { Positive Ranks } \\
\text { Ties } \\
\text { Total }\end{array}$ & $\begin{array}{r}3 \\
17 \\
6 \\
26\end{array}$ & $\begin{array}{r}5.00 \\
11.47\end{array}$ & $\begin{array}{r}15.00 \\
195.00\end{array}$ & -3.412 & .001 \\
\hline 13. & $\begin{array}{l}\text { Negative Ranks } \\
\text { Positive Ranks } \\
\text { Ties } \\
\text { Total }\end{array}$ & $\begin{array}{r}0 \\
23 \\
3 \\
26\end{array}$ & $\begin{array}{r}.00 \\
12.00\end{array}$ & $\begin{array}{r}.00 \\
276.00\end{array}$ & -4.280 & .000 \\
\hline 14. & $\begin{array}{l}\text { Negative Ranks } \\
\text { Positive Ranks } \\
\text { Ties } \\
\text { Total }\end{array}$ & $\begin{array}{r}1 \\
19 \\
6 \\
26\end{array}$ & $\begin{array}{r}4.50 \\
10.82\end{array}$ & $\begin{array}{r}4.50 \\
205.50\end{array}$ & -3.822 & .000 \\
\hline 15. & $\begin{array}{l}\text { Negative Ranks } \\
\text { Positive Ranks } \\
\text { Ties } \\
\text { Total }\end{array}$ & $\begin{array}{r}1 \\
22 \\
3 \\
26\end{array}$ & $\begin{array}{r}5.00 \\
12.32\end{array}$ & $\begin{array}{r}5.00 \\
271.00\end{array}$ & -4.092 & .000 \\
\hline 16. & $\begin{array}{l}\text { Negative Ranks } \\
\text { Positive Ranks } \\
\text { Ties } \\
\text { Total }\end{array}$ & $\begin{array}{r}2 \\
15 \\
9 \\
26\end{array}$ & $\begin{array}{l}5.00 \\
9.53\end{array}$ & $\begin{array}{r}10.00 \\
143.00\end{array}$ & -3.213 & .001 \\
\hline 17. & $\begin{array}{l}\text { Negative Ranks } \\
\text { Positive Ranks } \\
\text { Ties } \\
\text { Total }\end{array}$ & $\begin{array}{r}3 \\
18 \\
5 \\
26\end{array}$ & $\begin{array}{r}6.00 \\
11.83\end{array}$ & $\begin{array}{r}18.00 \\
213.00\end{array}$ & -3.459 & .001 \\
\hline 18. & $\begin{array}{l}\text { Negative Ranks } \\
\text { Positive Ranks } \\
\text { Ties } \\
\text { Total }\end{array}$ & $\begin{array}{r}11 \\
22 \\
3 \\
26\end{array}$ & $\begin{array}{r}5.50 \\
12.30\end{array}$ & $\begin{array}{r}5.50 \\
270.50\end{array}$ & -4.101 & .000 \\
\hline 19. & $\begin{array}{l}\text { Negative Ranks } \\
\text { Positive Ranks } \\
\text { Ties } \\
\text { Total }\end{array}$ & $\begin{array}{r}1 \\
5 \\
10 \\
26\end{array}$ & $\begin{array}{l}4.00 \\
8.80\end{array}$ & $\begin{array}{r}4.00 \\
132.00\end{array}$ & -3.361 & .001 \\
\hline 20. & $\begin{array}{l}\text { Negative Ranks } \\
\text { Positive Ranks } \\
\text { Ties } \\
\text { Total }\end{array}$ & $\begin{array}{r}3 \\
15 \\
8 \\
26\end{array}$ & $\begin{array}{r}5.00 \\
10.40\end{array}$ & $\begin{array}{r}15.00 \\
156.00\end{array}$ & -3.130 & .002 \\
\hline
\end{tabular}


Table 4 demonstrates the results of data analysis obtained from the pre- and postquestionnaire administered to the experimental group.

As seen in Table 4, the pre- and post-tests of the control and experimental groups have yielded significant changes. There is no statistically significant increase between pre- and post- administration of the questionnaire to the control group. However, this is not the case for the experimental group if we consider $p$ values of both groups.

Findings from the Interviews

The interview questions were developed by the researcher. It was a semi-structured interview that consisted of 17 questions. The questions of the interview were developed with respect to the reading skills mentioned in the study.

From the first interview:

Excerpt 1

T: Does your background knowledge affect your understanding a text?

S1: I mean it does. There can be words related to it. It affects positively. It makes the text easier to understand.

From the second interview:

\section{Excerpt 2}

T: Does your background knowledge affect your understanding a text?

S1: It does if I know something about the subject beforehand.

In both interviews, the participant responded in a way that he recognized the role of background knowledge, or schemata, affect the level of understanding a text.

From the first interview:

\section{Excerpt 3}

T: Can you find out the main and supporting ideas in a text you read?

S5: Generally, I can find them out.

In this interview, the participant is not quite sure about main and supporting ideas in a text. However, in the second interview, the participant is aware of the importance of main and supporting ideas in a text.

From the second interview:

Excerpt 4

T: Can you find out the main and supporting ideas in a text you read?

S4: I can find them out. The main idea is important. If you do not understand it, you read in vain.

From the first interview:

\section{Excerpt 5}

T: Do you understand the information in a text that is not stated explicitly?

S9: I sometimes understand them. 
From the second interview:

\section{Excerpt 6}

T: Do you understand the information in a text that is not stated explicitly?

S9: I understand them and I think they embellish the text. Irony, for example; it is very interesting. It makes us think in both ways.

From the first interview:

Excerpt 7

T: Can you find the meanings of unknown words in texts?

S4: It is difficult to understand a text if I do not know the meaning of unknown words, but I make guesses.

In the first interview, it is obvious that the participant is not aware of how to figure out the meaning of unknown words in a text. Conversely, the participant is aware of the skill in the second interview.

From the second interview:

Excerpt 8

$\mathrm{T}$ : Can you find the meanings of unknown words in texts?

S4: Yes, I can; especially in the exams.

T: How?

S4: I read the text and try to find synonyms, antonyms or examples for the unknown words. It usually works.

From the first interview:

Excerpt 9

$\mathrm{T}$ : Does the genre of a text affect your understanding?

S8: Teacher, it depends on the subject and the style of the writer.

From the second interview:

Excerpt 10

$\mathrm{T}$ : Does the genre of a text affect your understanding?

S8: I can figure out the genre. It can be easily understood through the use of certain key words. It says "Once upon a time...", for example and it uses past tense.

Above are some excerpts selected from the interviews that were conducted with some participants of the study. The responses of participants display the level of their achievement in reading skills throughout the study. The following section includes conclusion and discussion of the findings. 


\section{Conclusion}

The aim of this case study was twofold; (1) to find out whether or not Turkish EFL students were aware of reading skills, and (2) whether or not they could use appropriate reading skills if gained through a training program.

The first research question of this study seeks answers to whether or not the students are aware of reading skills. The results of The Reading Skills Questionnaire analysis which consists of 18 items were computed in order to find out whether or not the participants were aware of the reading skills. The questionnaire was conducted at the beginning of the study and it was the first instrument used to collect data for this study to find answers to the first research question. The questionnaire contained 12 reading skills and 3 micro skills and it was also conducted at the end of the study.

The analysis of the data showed that there exists a significant difference between the pre- and post- administrations of the questionnaire in all of the items. Thus, we can conclude that the students were not aware of the reading skills at the beginning of the study. The data gathered from the questionnaire were supported by the interviews and reveal a positive change in awareness of the reading skills.

The second research question of this study aims to find out whether or not the students can be trained in terms of reading skills. The data obtained from the pre-and post-test, Reading Skills Questionnaire, and interviews have shown that the students can be trained in terms of reading skills. Before the training, the students used to complain about inadequate comprehension of reading texts in the quizzes and exams. Having been equipped with the reading skills and achieving proficiency, they have shown that they enhanced their reading comprehension ability.

The third research question of this study seeks an answer to the question of whether students who are trained on reading skills are better at reading comprehension than those who are not. Bedir (2000), and Yilmaz (2013) state that readers who do not possess the knowledge of the skills are more likely to fail when they read a text. Some other researchers such as Carrell, Pharis, and Liberto (1989), and Nuttall (1996), and Canli and Canli (2013) also share this view. Similarly, Pani (2004) contends that students need training in terms of strategies so that they would become competent readers. According to Istifci (2009), and Celik, Akin, and Saricam (2014) the students understand more if they participate actively in the reading lesson by applying strategies.

When the overall analysis of the data is considered, it is seen that the students who are trained on reading skills are better at reading comprehension than those who are not. For instance, many of them were lacking the reading skill required to find the main idea and supporting ideas in a text, but, in the end they gained the skill and accomplished the tasks. They realized that they did not have to decode every single word in a text in order to comprehend it.

Moreover, the data gathered through the interviews revealed that students started to feel more confident towards the end of the study. There was a meaningful change in the participants' attitudes towards reading comprehension. Being aware of the reading skills and knowing how to use them efficiently while dealing with texts, the participants seemed to be more comfortable with the tests at the end of the study. 
It is well known that there exists a relationship between the language skills. A well written text can be a good model for the students, for example. It can help the students to improve their writing skills. That is to say, reading and writing are related to each other. Similarly, reading and listening are related to each other. Zamel (1992) notes that reading and writing are complementary acts. Students must become better at reading to become better at writing.

To conclude, when the research questions of this study are considered, we reached a number of results. Firstly, we realized that the students were not aware of the reading skills. Secondly, we understood that the students could be trained in terms of reading skills and that the training could enhance their comprehension ability. In addition, the trained students (experimental group) outperformed the other 'untrained' (control) group. Finally, we realized that reading skills have positive effects on writing skills. Briefly, this study reveals that if the students are trained to gain the appropriate strategies which facilitate understanding, they are likely to be more successful in reading comprehension. Thus, reading comprehension can be facilitated by enabling students to gain and use reading skills.

This study was conducted during one semester. A further study could last for a longer period; a full academic year, for instance. Reading skills are not easy to learn in just a short period of time. It may take several years for EFL students to become strategic readers. Further research could be conducted on the effect of gender or age on reading skills, or whether or not reading skills can be transferred to other language skills.

\section{Notes}

This study is produced from a Master's Thesis submitted at Cukurova University.

\section{References}

Alderson, J. C. (2000). Assessing reading. Cambridge: Cambridge University Press.

Bedir, H. (1998). The effect of using cognitive learning strategies on reading comprehension ability of Turkish students. Doctoral Dissertation. The Institute of Social Sciences, Cukurova University, Adana, Turkey.

Bedir, H. (2000). Maintenance of cognitive and metacognitive strategies used by ELT students in reading comprehension. Encouraging strategic classroom applications, Yadim-Inged Conference 2000 Proceedings (pp. 32-45). Adana: Cukurova University.

Block, E. (1992). See how they read: Comprehension monitoring of L1 and L2 readers. Tesol Quarterly, 26(2), 319-343.

Brown, H. D. (2001). Teaching by principles: An interactive approach to language pedagogy (2nd ed.). New York: Addison Wesley Longman.

Canli, Z., \& Canli, B. (2013). Keep Calm and Say Sorry!: The use of Apologies by EFL Teachers in Turkish and English. Educational Process: International Journal, 2(1-2), 36-46.

Carrell, P. L., Pharis, B. G., \& Liberto, C. J. (1989). Metacognitive strategy training for ESL reading. Tesol Quarterly, 23(4), 72-103.

Celik, I., Akin, A., \& Saricam, H. (2014). A Scale Adaptation Study Related to the Examination of Adolescents' Levels of Educational Stress. Üniversitepark Bülten, 3(1-2), 44-55.

Eskey, D. E. (1983). Learning to read versus reading to learn: Resolving the instructional paradox. English Teaching Forum, 12(3), 129-132. 
Goodman, K. (1967). Reading, a psycholinguistic guessing game. Journal of the Reading Specialist. In H. D. Brown (Ed.), Teaching by principles: An interactive approach to language pedagogy (2nd ed.) (pp. 126-135). New York: Addison Wesley Longman.

Hellyer, R., Robinson, C., \& Sherwood, P. (2001). Study skills for learning power (2nd ed.). Boston: Houghton Mifflin Company.

Istifci, I. (2009). Lexical inferencing strategies of Turkish EFL learners. Journal of Language and Linguistic Studies, 5(1), 97-109.

Kalayci, S. (2012). "A Journey to Bilingualism" A Case Study of German-Turkish Bilingual Family. Educational Process: International Journal, 1(1-2), 29-38.

Kalayci, S., \& Humiston, K. R. (2015). Students' Attitudes Towards Collaborative Tools In A Virtual Learning Environment. Educational Process: International Journal, 4(1-2), 7186.

Langan, J. (1992). Reading and study skills (5th ed.). New York: McGraw-Hill, Inc.

Mikulecky, B. S., \& Jeffries, L. (2004). More reading power: Reading for pleasure, comprehension skills, thinking skills, reading faster (2nd ed.). New York: Pearson Education.

Nuttall, C. (1996). Teaching reading skills in a foreign language. Oxford: MacMillan Publishers.

Pani, S. (2004). Reading strategy instruction through mental modelling. ELT Journal, 58(4), 355-362.

Pirozzi, R. (1995). Strategies for reading and study skill. Chicago: NTC Publishing Group.

Rathert, S. (2012). Functions of Teacher and Student Code-Switching in an EFL Classroom and Pedagogical Focus: Observations and Implications. Educational Process: International Journal, 1(1-2), 7-18.

Rivas, R. M. M. (1999). Reading in recent ELT coursebooks. ELT Journal, 53(1), 12-21.

Yılmaz, K. (2013). 10 soruda 4+4+4 eğitim sistemi. Üniversitepark Bülten, 2(2).

Zamel, V. (1992). Writing one's way into reading. Tesol Quarterly, 26(3), 463-485. 